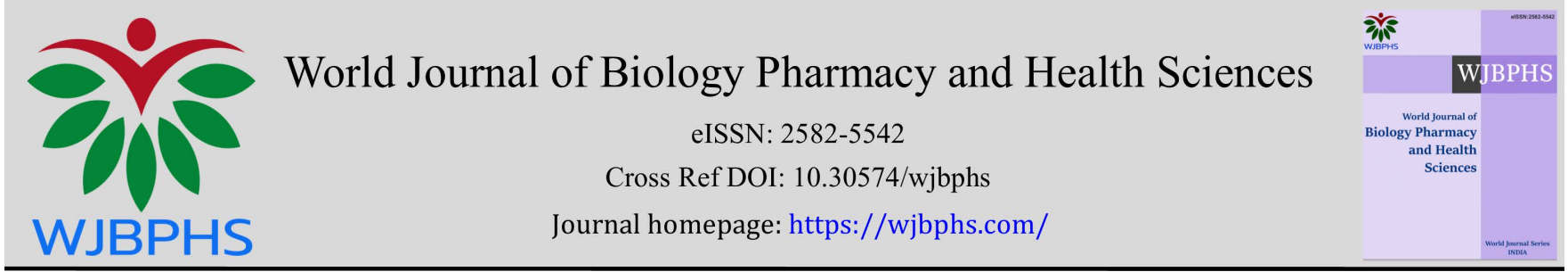

(REVIEW ARTICLE)

\title{
The use of starter cultures in the meat industry and their effect on the quality of meat products - A review
}

\author{
Dragutin Djukić ${ }^{1}$, Monika Stojanova ${ }^{2,}$, , Slavica Vesković-Moračanin ${ }^{3}$, Marina Todor Stojanova ${ }^{2}$ and Aziz \\ Şatana ${ }^{4}$ \\ ${ }^{1}$ University of Kragujevac, Faculty of Agronomy, Cacak, Serbia. \\ 2 University of Ss. Cyril and Methodius, Faculty of Agricultural Sciences and Food, Skopje, North Macedonia. \\ ${ }^{3}$ Institute of Meat Hygiene and Technology, Belgrade, Serbia. \\ ${ }^{4}$ Erciyes University, Agriculture Faculty, Kayseri, Turkey.
}

World Journal of Biology Pharmacy and Health Sciences, 2021, 07(03), 046-056

Publication history: Received on 04 August 2021; revised on 14 September 2021; accepted on 16 September 2021

Article DOI: https://doi.org/10.30574/wjbphs.2021.7.3.0093

\begin{abstract}
The use of certain types of microorganisms or their metabolic products is the basis for the development of new technologies, which on the one hand can contribute to the standardization of the production process and achieve uniform quality, and on the other hand to obtain quality and safe products with extended shelf life. On the world market for food and beverages, today can be find a wide range of commercial, fermented products in which production and sustainability certain microorganisms are participate. The interest in the new methods of biological protection of food, as well as the scientific principles for achieving health of the products has increased significantly in recent years. The increase in the need for quality and health-safe food has led to an increased interest in the use of starter cultures in the food industry, and especially in the meat industry. With the use of the starter cultures, good quality of the products is achieved. At the same time a safe product is obtained, where the use of the synthetic additives and theirs side effects on consumer's health is completely eliminated.
\end{abstract}

Keywords: Starter cultures; Meat industry; Food safety; Metabolic products

\section{Introduction}

The growing need for safe food that does not contain chemical additives, but also food that has the desired sensory characteristics, increases the interest in the application of starter cultures [1]. Such microorganisms possess at least one of the important functional characteristics (organoleptic, nutritional and technological advantages or have a positive effect on consumer health) and therefore their use is a compromise between the demands of consumers on the one hand and the food industry on the other [1].

The use of certain types of microorganisms or their metabolic products is the basis for the development of new technologies, which on the one hand can contribute to the standardization of the production process and achieve uniform quality, and on the other hand to obtain quality and safe products with extended shelf life. In addition, lactic acid bacteria or yeasts are most often used, whose metabolic and biosynthetic properties provide better nutritional, physic-chemical and organoleptic properties of meat products [2]. Also, the use of starter cultures in the food industry is of great economic importance, which contributes to reducing or eliminating the problems that occur in the quality and safety of food products, but also the global food deficit. Therefore, the search for natural food protection, in terms

\footnotetext{
${ }^{*}$ Corresponding author: Monika Stojanova

University of Ss. Cyril and Methodius, Faculty of Agricultural Sciences and Food, Skopje, North Macedonia. 
of the use of chemicals, is a logical approach given the fact that nature abounds in a large selection of antimicrobial compounds, which are carriers of bio-conservation of food $[3,4]$.

\section{Starter cultures in the meat industry}

On the world market for food and beverages, today can be find a wide range of commercial, fermented products in which production and sustainability certain microorganisms are participate. The work of the wine, beer and alcohol industry could not be imagined without the use of appropriate yeasts [5]. At the same time, lactic acid bacteria have an essential role in products whose production is based on lactic acid fermentation (milk, meat and vegetable industry), while some types of microorganisms are used to produce organic acids, vitamins, vaccines and enzymes [6].

The result of this development of biotechnology is confirmed by the data that $25 \%$ of the diet in Europe, as well as $60 \%$ of the diet in other more developed countries in the world, is based on the use of fermented food. Hence, it is estimated that to date there are more than 3500 different types of fermented products worldwide [7].

The traditional production of fermented products, as well as the use of microorganisms in the food industry is based on the activity of the so-called "wild" microbial communities, where the process of lactic acid fermentation is spontaneous and uncontrolled, and as a result, the quality of such products is uneven and without previously established sensory properties. This form of fermentation is based solely on empirical knowledge that certain foods, some with extended shelf life, are changing in terms of obtaining new and improved sensory properties, as well as significantly greater sustainability of the raw material. The direction of such a process is conditioned by the activity of the accidentally present microbial communities and often can have an undesirable course, ie lead to spoilage of the finished product [8].

Therefore, obtaining quality end products is possible only if during fermentation beneficial, homofermentative types of lactic acid bacteria are dominated, otherwise production errors are very common [9].

In order to properly control fermentation, while eliminating unwanted microorganisms, a number of chemicals are used in the food industry, which in turn can be a potential health risk to consumers. Hence, the consumers increasingly show a negative attitude towards the use of chemicals (additives) in food production. As a result, consumers are undecided about the use of any treated or fresh food that contains additives [10].

In order to minimize such risks, modern production of fermented products is possible only if certain principles are observed [11]:

- $\quad$ reduction of random ("wild") microbial communities;

- use of the necessary chemical substances in minimal quantities;

- introduction of selected types of microorganisms (starter cultures) in the production process.

With the direct addition of starter cultures in the raw material, the fermentation process is shortened and the degree of control and standardization of the overall production is increased. In other words, the increasing needs for quantities of fermented products, the needs for standardized and economical production, as well as for obtaining health-safe products, condition the use of active starter cultures [12].

It is impossible for such a small stream, as was our initial examination of bacterial cultures 40 years ago, to grow into a river that is very important to industry. Who would have thought that the use of starter cultures would be the basic direction of today's movement.

These are the words of the pioneer of starter cultures used in meat, Niinivaara (1955) [13] who saw the significance of the application of starter cultures in the meat processing industry. The idea of applying starter cultures of the genus Lactobalillus sp. in the production of fermented sausages was first introduced in 1940 by Jensen and Paddock [14] as a way to shorten the ripening time and achieve the required quality and aroma. The first application of starter cultures in the meat industry in the United States in 1955 marked the use of Pediococcus cerevisiae. At the same time, Niinivaara in 1955 [13] introduced the bacterium Micrococcus M53 in meat production in Europe [14].

The used microorganisms with certain desirable physiological and metabolic properties are isolated from natural environments or from quality fermented products. Their use is based on numerous studies, including examination of 
the acidification process and phage resistance. The cells thus obtained must be properly maintained and stored, which is achieved by the process of lyophilization or conventional freezing [14].

Starter cultures are a large number of cells prepared in a special, microbiological way, usually from a type of microorganism, which added to the initial raw material leads to the formation of a fermented product by accelerating and controlling the fermentation process itself. Some authors, in the definition of starter cultures, state that these are "preparations containing living organisms or their form of dormancy, which develop in the fermentation substrate fulfilling their desired metabolic activity" [15]. Most often, but not necessarily, the added microorganisms need to multiply in the substrate, ie. in the raw material.

Selected microorganisms must undergo numerous tests for detailed analysis and definition of the quality of their genetic, biochemical and functional characteristics. In addition to accurate molecular-genetic identification, pure culture must possess stable and desirable physiological properties, adapted to the substrate to which it is added [16]. At the same time, with its metabolic activity it must direct and accelerate the process until the creation of desirable sensory properties. But above all, the starter culture used must be harmless to the health of consumers [17].

In addition to achieving positive sensory changes and obtaining products with desirable properties, the added starter cultures are expected to provide optimal microbiological flow, thus ensuring production safety. That is, the positive impact of starter cultures added to the substrate in the finished product can be manifested through several positive benefits [18]:

- $\quad$ impact on health safety;

- impact on stability, ie. product sustainability;

- $\quad$ beneficial effect on consumer health;

- variety of products.

According to Vesković and Obradovič (2009) [19], many years of research have been conducted on the territory of the Republic of Serbia in order to identify the diversity of different bacterial species of the genera Lactobacillus, Micrococcus, Staphylococcus and Streptococcus, which are actually carriers of fermentation of traditional sausages ("Sremski", "Uzichki" and "Levachki" sausage) and to determine the possibility of their application in industrial conditions. With proper selection of certain strains of bacteria, after detailed morphological, biochemical and molecular-genetic studies, as well as determination of potential technological, protective and probiotic properties, conditions for own production of starter cultures would be created [20]. With their application, further, specific national products would be obtained, with characteristic and recognizable sensory properties, with improved quality parameters. In that way, authentic products with equal quality can be obtained, production errors will be eliminated, and the maturation and drying process will be shortened [21].

The original preservation of naturally fermented meat products was due to the combined action of biochemically active lactic acid bacteria found naturally in meat, the nitrates present and the high salt content. However, the demands for increased production after the Second World War, conditioned the need for standardization and economy of production on the one hand, and obtaining a safe product on the other hand, due to which the intensive application of starter cultures began worldwide [12].

\subsection{The influence of the starter cultures on the quality of meat products}

In the modern food industry, a major challenge is the identification and proper application of certain species of bacteria that are able to actively change color during the production of meat products. Many bacteria are known to be able to reduce $\mathrm{MbFe}_{3}{ }^{+}$to $\mathrm{MbFe}_{2}{ }^{+}$, which binds atmospheric oxygen to form an intense red color [22], although only a few strains have been identified that can form $\mathrm{MbFe}_{2}+\mathrm{NO}$ without presence of nitrites and nitrates [23]. 


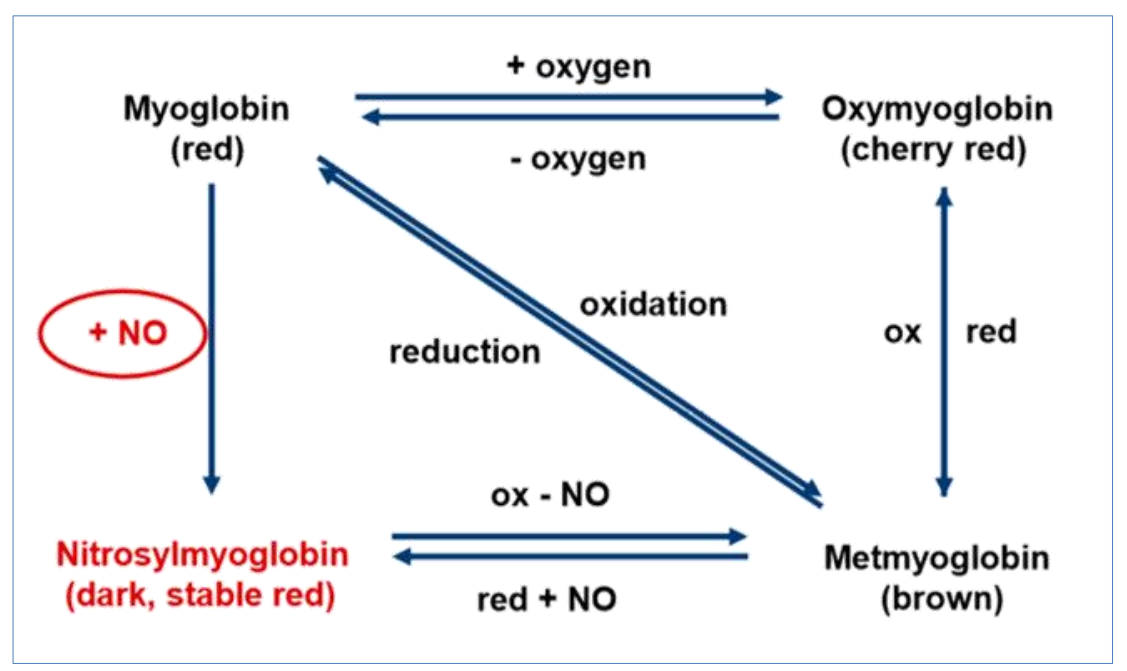

Figure 1 Colour formation in the sausages (Bacus, 2006) [24]

The identification of bacteria that form $\mathrm{MbFe}_{2}+\mathrm{NO}$, leads to the development of the theory that the optimal color that is formed during the maturation process of meat products without the addition of nitrites is the result only of the activity of added microorganisms [25, 26].

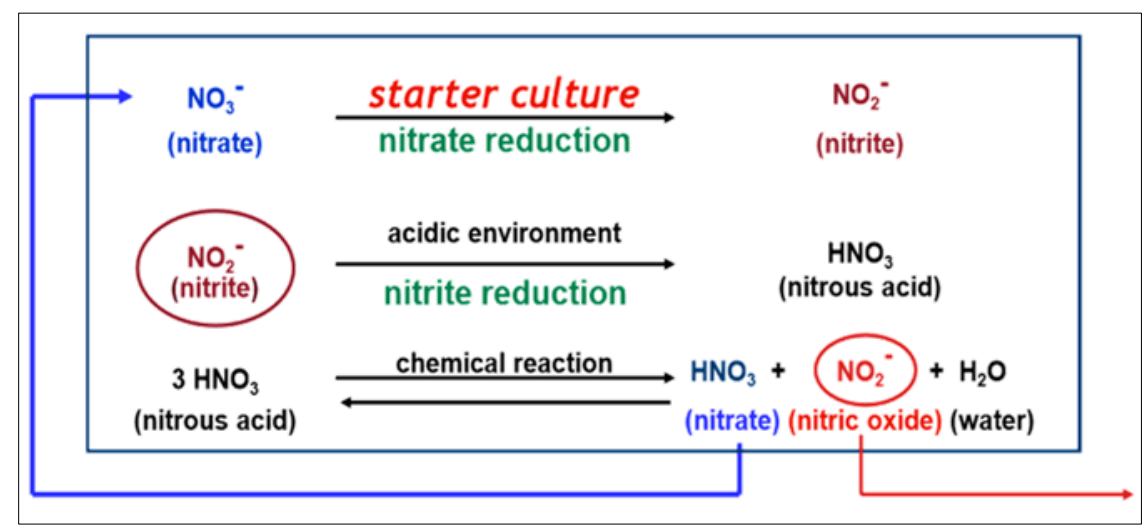

Figure 2 Colour for mation in the sausages using starter cultures (Bacus, 2006) [24]

Numerous studies show that lactic acid bacteria in some cases can synthesize NO, ie show bacterial activity that could be used to form color in meat products [27]. The knowledge that such enzymes can be found in many pathogenic species, such as Staphylococcus aureus, means the presence of similar types of enzymes in other non-pathogenic staphylococci, which is important in the formation of the desired sensory characteristics of sausages [28]. The formation of MbFe $2+\mathrm{NO}^{2}$ with the active participation of starter cultures is a complex biochemical process that leads to the formation of nitro derivatives of myoglobin [26, 29].

Casaburi et al. (2007) [1] investigated the impact of starter cultures on the biochemical and sensory characteristics of traditionally fermented Vallo di Diano sausages from Northern Italy. Two starter cultures were used: Staphylococcus xylosus, isolated from traditional sausages (one with lipolytic properties - S1 and one with proteolytic properties - S2) and Lactobacillus curvatis. In the third, control variant no starter culture was added. At the end of maturation, the $\mathrm{pH}$ of the samples S1 and S2 was between 5.49 and 5.59, and the $\mathrm{pH}$ of the control variant of 6.18 during maturation dropped to 5.57. Based on the results of the color analysis, they concluded that the starter cultures did not significantly affect the color change. Larger changes in $L^{*}$ and $a^{*}$ values were observed after the $28^{\text {th }}$ day of maturation. On the other hand, Casquete et al. (2011) [31] found that the addition of indigenous starter cultures (Pediococcus acidilactici and Staphylococcus vitulus) and protease EPg222 had no effect on color in traditional Salchichón Iberian sausages. The average values of the color parameter, determined for Salchichón sausages were: $\left(L^{*}\right) 41.55 ;\left(a^{*}\right) 15.88 ;\left(b^{*}\right) 12.30$.

Magrinyà et al. (2015) [32] investigated the impact of different nitrite sources in combination with starter cultures CS300 (Staphylococcus carnosus) and B-FM (Lactobacilus sakei and Staphylococcus xylosus) and tocopherol extract on the 
quality of boiled sausages. The authors found that the $L^{*}$ values from the instrumental color analysis were the highest (63.73) in the sausages in which the two starter cultures CS-300 and B-FM were applied. The authors also pointed out that the content of residual nitrites in sausages produced with the starter culture Staphylococcus carnosus is higher (4.50 ppm) compared to the sausages in which the starter cultures Staphylococcus carnosus and Staphylococcus xylos were applied.

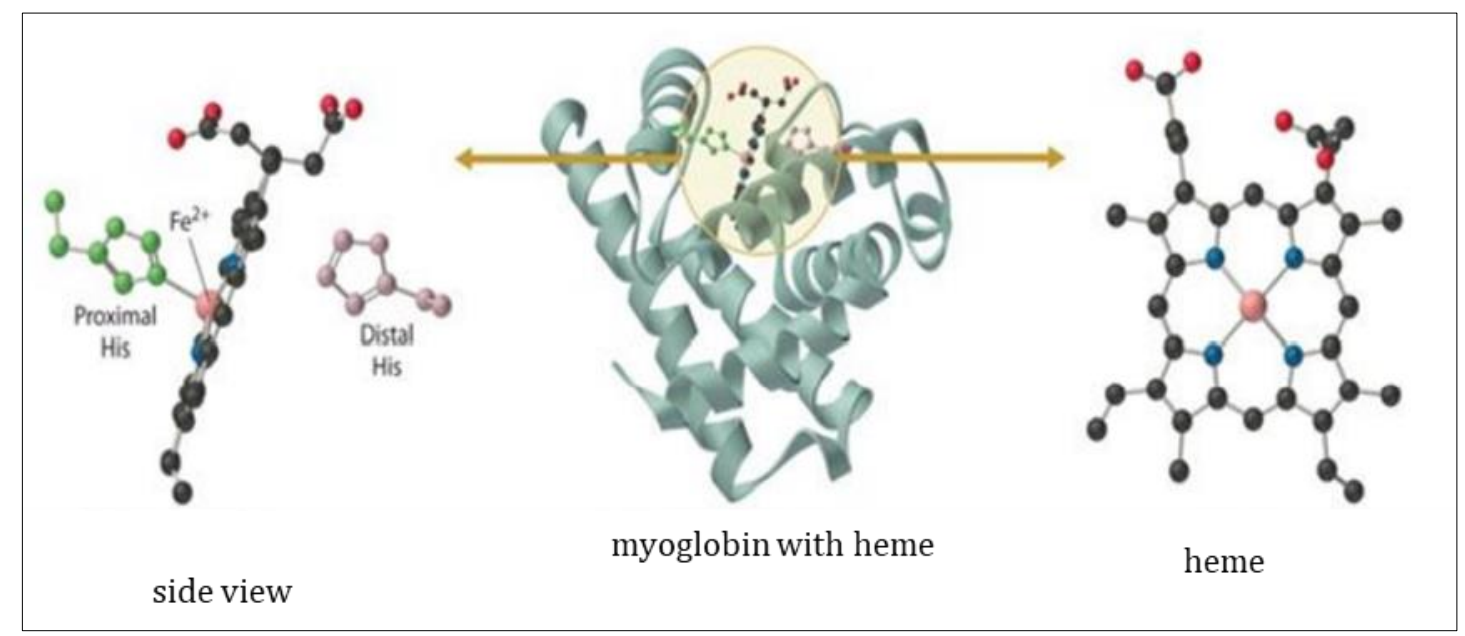

Figure 3 Schematic representation of $\mathrm{Fe}_{2}{ }^{+}$binding from heme with proximal histidine depth (Averill and Eldredge, 2013) [30]

In addition to the color, the characteristic smell, taste and aroma of sausages is a result of the combined action of the basic ingredients they contain, such as the type of meat, additives (sugar, salt, spices), the method of technological processing, the use of smoke, as well as the type and the intensity of metabolic processes by the added microorganisms [33]. To obtain the smell, taste and aroma, key processes are glycolysis, proteolysis, lipolysis and oxidation of lipids, which take place during the process of maturation or fermentation [34]. Carriers of these activities are endogenous enzymes of meat and enzymes of the present microorganisms. Leroy et al. (2006) [17] found that technological parameters such as temperature, relative humidity, thickness and type of wrappers, the size of pieces of meat, as well as the amount and type of adipose tissue also influence the formation of the final sensory properties of sausages. Hierro et al. (1999) [35] indicate that proteolytic enzymes, primarily meat-derived endogenous enzymes, have a major influence on sausage flavor. Meat protease, especially cathepsin D - as an enzyme, is responsible for the process of proteolysis and the formation of free peptides during fermentation. On the other hand, Hughes et al. (2003) [36, 61] found that microbial enzyme systems mainly act on the oligopeptides present during the late maturation phase. Molly et al. (1997) [37] pointed out that the proteolytic activity of microorganisms is low in the conditions present in the production of fermented sausages, but some activity, although to a lesser extent depending on the type and strain of the microorganisms present, may contribute to the partial breakdown of proteins. Proteolytic microbial activity is considered an important property because in this process the peptides are intracellularly translated into amino acids, and they can be further converted into components important for the aroma of sausages [38]..

In addition to influencing the formation of taste, lactic acid bacteria also influence the change of acidity in the finished products by creating various by-products. In this context, Garcia et al. (1992) [39] found that by decreasing the $\mathrm{pH}$ value of sausages, tissue enzymes that are carriers of lipolysis and proteolysis are activated. Lactic acid bacteria usually do not have strong proteolytic and lipolytic properties, although some activity of their peptidase and lipase is observed.

Demeyer et al. (2000) [20] indicate that bacterial enzymes in combination with muscle aminopeptidase, contribute to the production of free amino acids that affect the final taste of sausages. But Larrouture et al. (2000) [40] found that their catabolic effect was significantly lower in pediococci compared with staphylococci. It is therefore considered that, Pediococcus sp. do not have a major role in forming the typical sausage aroma. Pediococcus acidilactici are good initiators of the acidification of meat dough, but cannot always prevent the growth and development of already present, nonstarting lactic acid bacteria, as well as their undesirable effect on the final product. The positive effect of staphylococci and micrococci is due to the reduction of nitrates and the effect of their proteolytic and lipolytic properties [41]. The lipolytic processes that take place in meat under the action of endogenous lipases produce more than $60 \%$ of free amino acids that are precursors of aroma. The bacterium Staphylococcus sp., which is commonly used as a starter culture in the meat industry in the production of sausages, has been found to produce a variety of volatile components that carry 
the aroma. According to Viallon et al. (1996) [42] Staphylococcus carnosus is a carrier of the pungent, specific odor of dried salami due to the formation of 3-methylbutanate, methyl ketones and ethyl ester.

Lipolysis is the first step in the process of fat breakdown, followed by the processes of oxidative breakdown of free fatty acids and the production of alkanes, alkenes, alcohols, aldehydes and ketones [42]. In general, the microbial community present influences the oxidation processes of free fatty acids, although non-enzymatic reactions are thought to play a major role.

Hugas and Monfort (1997) [36] also investigated the lipolytic activity of lactobacilli in the process of fermentation of sausages, and in vitro, this property was found in Lactobacillus sakei, Lactobacillus curvatus and Lactobacillus plantarum. Lactobacillus lipase is thought to show little activity in the conditions present in sausages.

The primary contribution of lactic acid bacteria in the formation of the final taste of meat products is attributed to the production of large amounts of lactic and partially acetic acid, which, in turn, occur as a result of fermentation of carbohydrates [43].

In Northern Europe, in addition to lactic acid, for smoked fermented sausages, the technological process of processing is very important, which affects the formation of the final taste of the products. But Erkkla et al. (2001) [44] pointed out that acetic acid, which is present in small quantities, has a significant contribution to the final taste, and the excessive concentration of this acid leads to the formation of products with pronounced acidity and specific, unpleasant aroma, which makes such sausages unacceptable among the consumers.

According to Djukic and Veskovic (2015) [45], in sausages that have low acidity, and the smoking procedure is rarely used, the taste is primarily a result of the proteolytic and lipolytic activity of tissue enzymes, as well as the metabolic activity of the added starter cultures. It is known that certain types of moulds or yeasts are inoculated on the surface of Mediterranean sausages, which contribute to the formation of positive sensory properties.

The use of certain types of microorganisms, as part of the starter cultures that produce components that are of great importance for the aroma of the product, results in a pleasant taste, as well as shortening the maturation time. Starter cultures, on the other hand, also control the decrease of the $\mathrm{pH}$ value of the environment, which enables inhibition of the growth of undesirable microorganisms, which increases the safety and stability of the final product [41].

This indicates the fact that the reduction of the $\mathrm{pH}$ value is a basic physic-chemical, and also the most important change during the process of fermentation of sausages on which depends the sustainability of the product, creating a stable color, bonding the mixture and forming a good consistency and aroma of the sausages. Carriers of sausage fermentation are the bacteria Lactobacillus, Lactococcus, Pediococcus, Enterococcus and the yeasts Debaryomyces and Streptomyces [46].

Most lactic acid is produced by homofermentative species (over 95\%). In his research, Vukovič (2006) [47] concludes that in the first phase of sausage ripening there is a decrease in the number of aerobic, gram-negative bacteria, primarily from the families Pseudomonadaceae and Enterobacteriaceae, while lactic acid bacteria that are acid-tolerant and resistant to salt concentrations and microaerophilic conditions, multiply better. On the other hand, the author pointed out that catalase-positive bacteria (primarily bacteria of the genera Staphylococcus and Kocuria) affect the formation of the desired sensory characteristics of the product.

\subsection{The most common used starter cultures and their effects in the sausage production}

The selected strains of microorganisms used as starter cultures must be dominant in the production of sausages (or any other meat product) and well adapted to the environment in which they are found. Therefore, it is necessary to know well their nature, the technology of production of sausages, as well as the expected type of interaction between the used starter cultures. In this regard, Hammes and Hertel (1998) [48] pointed out that in the production of sausages the best effect is achieved by the use of catalase positive Staphylococcus carnosus. According to their knowledge, this bacterium reduces the concentration of nitrates and nitrites, consumes oxygen, destroys peroxide and creates esters. During the ripening of the sausages, Staphylococcus carnosus develops and stabilizes the color and taste.

Lücke and Hechelmann (1987) [49] gave a detailed explanation of the effect of starter cultures on fresh sausages. Namely, according to the authors, the color of sausages is achieved as a result of the reduction of nitrates, reduction of the $\mathrm{pH}$ value, reduction of the oxygen content and degradation of hydrogen peroxide. The aroma is obtained through 
the production of acids, proteolysis and lipolysis. Consistency is maintained by lowering the pH, and sustainability, in addition to controlling the $\mathrm{pH}$, is achieved by suppressing unwanted microflora.

In the presence of oxygen, lactic acid bacteria can produce hydrogen peroxide. Accumulation of this strong oxidant can lead to undesirable properties of the products, such as scorching and discoloration. Numerous studies show that some species of lactic acid bacteria possess catalase. In this regard, Olesen and Stahnke (2004) [50] determine that the strains Lactobacillus sakei and Lactobacillus plantarum have catalytic activity, but sometimes Lactobacillus plantarum can show false, pseudo-catalytic activity. In order to prevent side effects, catalase-positive strains are often used as part of starter cultures. Therefore, the further strategy is to allow strains that do not have catalase properties to realize this property (as is the case with Lactobacillus curvatus). This genetic modification allows the production of starter preparations without the need to combine Lactobacillus curvatus with catalase-positive species (such as Staphylococcus carnosus).

Apart from lactobacilli, which are usually added as starter cultures in the meat dough during the sausage production process, some other types of lactic acid bacteria can be added to obtain the desired taste. For example, enterococci show proteolytic, lipolytic, and esterolytic activity and play a significant role in the maturation and taste development of traditional fermented sausages [51,52]. Also, the addition of Lactococcus lactis ssp. cremoris can lead to higher amounts of free amino acids, and through their metabolism different types of aromatic compounds are formed that are important for the taste of sausages [53].

Pediococcus acidilactici, Pediococcus pentosaceus, Lactobacillus pentosus, and Lactobacillus plantarum are the most commonly used species used as part of commercial starter cultures for meat, and are rarely found in spontaneously fermented sausages, usually due to poor competition [54]. These types of bacteria are good initiators of the acidification of meat dough, but they cannot always prevent the development of existing non-starter lactic acid bacteria and their adverse effect on the final product [36]. On the other hand, according to Garriga et al. (1993) [55] the use of Lactobacillus plantarum may lead to the production of sausages with increased acidity, which is sensory undesirable for consumers.

According to the research of Aymerich et al. (2003) [56], although rapid acidification initiated by the metabolic activity of starter cultures reduces microbiological risks during sausage production, primarily the risk of Pseudomonadaceae and Enterobacteriaceae, however, the risk of pathogens is not eliminated. Staphylococcus aureus, Escherichia coli, Salmonella and Listeria monocytogenes are considered to be particularly pathogenic bacteria that may be present in food.

\section{The influence of the lactic acid bacteria on the meat products safety and consumers health}

The interest in the new methods of biological protection of food, as well as the scientific principles for achieving health of the products has increased significantly in recent years. The increase in the need for quality and health-safe food has led to an increased interest in the use of starter cultures in the food industry, and especially in the meat industry [9].

Although many starter cultures manufacturers point out that they can solve problems in terms of hygiene standards related to the basic components of the product, the product could not be expected to meet the quality and safety standards if at the beginning of production there is raw material problems [57].

Therefore, the application of protective cultures, in addition to starter cultures, to ensure microbiological food safety, carries certain risks, which primarily relate to uncertainty in the final outcome of the competition, growth rate and intensity of metabolic activity among the added starter or protective cultures and the already present, undesirable microflora. Accordingly, Arihara (2006) [58] suggests that the application of protective cultures should be seen only as an additional degree of protection in the production of meat products.

Starter cultures have a positive influence on the color, texture, lipid oxidation and sensory properties industrially produced Macedonian traditional sausage. According to the authors, with the use of the Staphylococcus carnosus ssp. utilis as a starter culture, good quality of the sausages is aschived. At the same time a safe product is obtained, where the use of the nitrite salt and its side effects on consumer's health is completely eliminated $[59,60]$.

The use of certain microorganisms is based on the development of new technologies of biological conservation and protection, whose application can contribute to the standardization process of making food products with uniform and/or improved quality parameters. The quest for a natural alternative to food safety, in relation to the use of chemical substances, is one of the most important activities of the food industry which is determined by the request of modern consumer to consume a minimum of processed foods $[15,61]$. 


\section{Conclusion}

The use of starter cultures in the industrial production of meat products is extremely important. Numerous studies are increasingly pointing out about the harmful effects that cumulatively can be caused by certain synthetic additives that are widely used in industrial production. On the other hand, many studies have found that with the use of properly selected starter cultures, better effects can be achieved, not only in terms of product safety, but also in terms of quality properties. The right choice of microorganisms depends on the type of the product and the aim that should be achieved. Therefore, it is considered that the starter cultures will be increasingly used in the future, especially in the industrial production of traditional meat products without addition of synthetic additives.

\section{Compliance with ethical standards}

\section{Disclosure of conflict of interest}

Authors declare there is no conflict of interest.

\section{References}

[1] Casaburi A, Aristoy MC, Cavella S, Di Monaco R, Ercolini D, Toldrá F, Villani F. Biochemical and sensory characteristics of traditional fermented sausages of Vallo di Diano (Southern Italy) as affected by the use of starter cultures. Meat Science. 2007; 76(2): 295-307.

[2] Ruiz - Moyano S, Martin R, Benito MJ, Hernández A, Casquete R, Guia Córdoba RD. Safety and functional aspects of pre-selected pediococci for probiotic use in Iberian dry - fermented sausages. Int. J. Food Sci. Technol. 2010; 45: $1138-1145$.

[3] Trichopoulou A, Soukara S, Vasilopoulou E. Traditional foods: A science and society perspective Trends. Food Science and Technology. 2007; 18: 498-504.

[4] Demeyer D. Meat fermentation: Principles and applications. In: Handbook of Food and Beverage Fermentation Technology, edited by H. Hui , L Meunier - Goddik A, Hansen J, Josephsen , W.-K. Nip , P. Stanfield, F. Toldrá. New York: Marcel Dekker. 2004.

[5] Ross RP, Morgan S, Hill C. Preservation and fermentation: past, present and future. International Journal of Food Microbiology. 2002; 79: 3-16.

[6] Bhat R, Allas AK, Pallyath G. Factors Affecting the Growth of Microorganisms in Food. John Willey \& Sons Ltd, USA. 2012.

[7] Holzapfel W, Geisen R, Schillinger U. Biological preservation of foods with reference to protective cultures, bacteriocins and food-grade enzymes. International Journal of Food Microbiology. 1995; 24: 343-362.

[8] Djukic D, Mandic L. Technology of microbiological productions. IP “Prosveta”, Belgrade, 2012.

[9] Djukic D, Mandic L, Veskovic S. General and industrial microbiology. University of Kragujevac, Faculty of Agronomy, Cacak. 2015.

[10] Cocconcelli PS, Fontana C. Bacteria, in Handbook of Fermented Meat and Poultry F. Toldra Ed. 117-128, John Wiley \& Sons, Ltd. 2015.

[11] Teodorovič V. Possibility of using bacteriocins in the meat industry. Meat Technology. 1996; 3-4: 173-176.

[12] Caplice E, Fitzgerald GF. Food fermentations: role of microorganisms in food production and preservation. International Journal of Food Microbiology. 1999; 50: 131-149.

[13] Niinivaara F. Uber den Einfluss von Bacterienreinkulturen auf die Reifung und Umrotung der Rohwurst. Avta Agr. Fenn., Helsinki. 1955; 84: 128.

[14] Veskovič MS, Stefanović S, Radicević T, Djukić D. Screening procedure for biogenic amine production by lactic acid bacteria isolated from traditionally fermented sausages. Journal of Hygienic Engineering and Design. 2014; 6: 202-207.

[15] Vesković-Moračanin S, Đukić D, Kurćubić V, Mašković P, Ač M. Natural antimicrobial compounds and biopreservation of food. Tehnologija mesa. 2015; 56(1): 16-25. 
[16] Elias M, Potes ME, Roseiro LC, Santos S, Gomes A, Agulheiro-Santos AC. The Effect of Starter Cultures on the Portuguese Traditional Sausage, Paio do Alentejo, in Terms of Its Sensory and Textural Characteristics and Polycyclic Aromatic Hydrocarbons Profile, Journal of Food Research. 2014; 3: 45- 56.

[17] Leroy F, Verluyten J, De Vuyst L. Functional meat starter cultures for improved sausage fermentation. International Journal of Food Microbiology. 2006; 106: 270-285.

[18] Lücke FK. Utilization of microbes to process and preserve meat. Meat science. 2000; 56: 105-115.

[19] Veskovič M, Obradovič D. Mikrobioloski ekosistem tradicionalnih fermentisanih kobasica u Srbiji - mogucnosti stvaranja sopstvenih starter kultura. Tehnologija mesa. 2009; 50(1-2): 60-67.

[20] Demeyer D, Raemaekers M, Rizzo A, Holck A, De Smedt A, ten Brink B, Hagen B, Montel C, Zanardi E, Murbreek E. Control of bioflavour and safety in fermented sausages: first results of a European project. Food research international. 2000; 33: 171-180.

[21] Vignolo G, Castellano P, Fadda S. Bioprotective Cultures, in Handbook of Fermented Meat and Poultry, F. Toldra, Ed., John Wiley \& Sons, Ltd. 2015.

[22] Arihara K, Cassens RG, Luchansky JB. Metmyoglobin reduction activity of enterococci. Fleischwirtsch. 1994; 74: 1203-1204.

[23] Morita H, Sakata R, Nagata Y. Nitric oxide complex of iron (II) myoglobin converted from metmyoglobin by Staphylococcus xylosus. Journal Food Science. 1998; 63: 352-355.

[24] Bacus J Natural Ingredients for Cured and Smoked Meats, Chr. Hansen Inc. 59th Reciprocal Meats Conference, Gainesville, Florida. 2006.

[25] Sakata R. Studies on physicochemical characteristics of red pigments in meat products. Animal Science Journal. 2000; 71: 1-16.

[26] Müller JKS, Skibsted LH Color. In: Handbook of fermented meat and poultry, edited by Toldrá F, Hui YH, Astiasarán I, Nip WK, Sebranek JG, Silveira ETF, Stahnke LH, Talon R, Ames, Iowa, USA: Blackwell Publishing. 2007; 203-216.

[27] Karahan AG, Cakmakci ML, Cicioglu-Aridogan B, Kart-Gundogdu A. Nitric oxide (NO) and lactic acid bacteria contributions to health, food quality, and safety. Food Reviews International. 2005; 21: 313-329.

[28] Chartier FJM, Couture M. Stability of the heme environment of the nitric oxide synthase from Staphylococcus aureus in the absence of pterin cofactor. Biophysical Journal. 2004; 87: 1939-1950.

[29] Berns RS. Billmeyer and Saltzman's Principles of Color Technology. Edition 3, Publishing Wiley \& Sons, New York. 2000.

[30] Averill B, Eldredge P. Transition Metals in Biology. In: Handbook General Chemistry: Principles, Patterns, and Applications. Flat World Knowledge, Inc. Terms of Use. 2013.

[31] Casquete R, Benito MJ, Martín A, Ruiz-Moyano S, Córdoba JJ, Córdoba MG. Role of an autochthonous starter culture and the protease EPg222 on the sensory and safety properties of a traditional Iberian dry-fermented sausage "salchichón". Food Microbiology. 2011; 28: 1432-1440.

[32] Magrinyà N, Bou R, Rius N, Guardiola F. Use of tocopherol extract and different nitrite sources and starter cultures in the production of organic botifarra catalana, a cooked cured sausage. Food Science and Technology International. 2015; 22: 221-234.

[33] Wang XH, Ren HY, Liu DY, Zhu WY, Wang W. Effects of inoculating Lactobacillus sakei starter cultures on the microbiological quality and nitrite depletion of Chinese fermented sausages, Food Control. 2013; 32(2): 591596.

[34] Zdolec N, Hadžiosmanović M, Kozačinski L, Cvrtila Ž, Filipović I, Leskovar K, Vragović N, Budimir D. Fermentirane kobasice proizvedene u domaćinstvu - mikrobiološka kakvoća. Meso, Vol. IX studeni - prosinac br. 2007; 6: 318324.

[35] Hierro E, De La Hoz L, Ordonez JA. Contribution of the microbial and meat endogenous enzymes to the free amino acid and amine contents of dry fermented sausages. Journal of Agricultural and Food Chemistry. 1999; 47: 11561161.

[36] Hugas M, Monfort JM. Bacterial starter cultures for meat fermentation. Food chemistry. 1997; 59: 547-554. 
[37] Molly K, Demeyer D, Johansson G, Raemaekers M, Ghistelinek M, Geenen I. The importance of meat enzymes in ripening and flavor generation in dry fermented sausages. First results of a European project. Food Chemistry. 1997; 59: 539-545.

[38] Lopez C, Medina LM, Priego R, Jordano R. Behaviour of the constitutive biota of two types of Spanish dry-sausages ripened in a pilot-scale chamber, Meat Science. 2006; 73: 178-180.

[39] Garcia ML, Selgas MD, Fernandez M, Ordonez JA. Microorganisms and lipolysis in the ripening of dry fermented sausages. Int. J. Food. Sci. Technol. 1992; 27: 675-682.

[40] Larrouture C, Ardaillon V, Pepin M, Montel MC. Ability of meat starter cultures to catabolize leucine and evaluation of the degradation products by using HPLC method. Food Microbiology. 2000; 17: 563-570.

[41] Ricke SC, Diaz IZ, Keeton JT Fermented Meat, Poultry, and Fish Products. in. Food Microbiology: Fundamentals and Frontiers, ASM Press, Washington, wash, USA. 2007.

[42] Viallon C, Bergaduc JL, Montel MC, Talon R, Martin JF, Kondjoyan N, Denoyer C. The effect of stage of ripening and packaging on volatile content and flavor of dry sausage. Food Research International. 1996; 29: 667-674.

[43] Molly K, Demayer D, Civera T, Verplaetse A. Lipolysis in a Belgian sausage: relative importance of endogenosus and bacterial enzymes. Meat science. 1996; 43: 235-244.

[44] Erkkila S, Petaja E, Eerola S, Lilleberg L, Mattila-Sandholom T, Suihko ML. Flavor profiles of dry sausages fermented by selected novel meat starter cultures. Meat science. 2001; 58: 111-116.

[45] Veskovic MS, Djukic D. Bioprotectors in food production. University of Kragujevac, Faculty of Agronomy, Cacak. 2015.

[46] Weber H. Mikrobiologie der Rohwurst. U: Mikrobiologie der Lebensmittel. Fleisch und Fleischerzeungnisse. Behrs Verlag, Hamburg. 1996; 313-338.

[47] Vuković I. Basic food technology. Veterinary Chamber Serbia, Belgrade. 2006.

[48] Hammes WP, Hertel C. New developments in meat starter cultures. Meat science 49: 125-138.1998;

[49] Lücke FK, Hechelmann H. Starter cultures for dry sausages and raw ham. Composition and effect. Fleischwirtschaft. 1987; 67: 307-314.

[50] Olesen PT, Stahnke LH. The influence of environmental parameters on the catabolism of branched-chain amino acids by Staphylococcus xylosus and Staphylococcus carnosus. Food Microbiology. 2004; 20: 621-629.

[51] Franz CAMP, Stiles ME, Schleifer KH, Holzapfel WH. Enterococci in foods - a conundrum for food safety. International Journal of Food Microbiology. 2003; 88: 105-122.

[52] Giraffa G. Studying the dynamics of microbial populations during food fermentation. FEMS Microbiology Reviews. 2004; 28: 251-260.

[53] Herranz B, Fernandez M, Hierro E, Bruna JM, Ordonez JA, de la Hoz L. Use of Lactobacillus lactis subsp. cremoris NCDO 763 and aketoglutarate to improve the sensory quality of dry fermented sausages. Meat science. 2004; 66: 151-163.

[54] Coppola S, Mauriello G, Aponte M, Moschetti, G, Villani F. Microbial succession during ripening of Naples-type salami, a southern Italian fermented sausage. Meat science. 2000; 56: 321-329.

[55] Garriga M, Hugas M, Aymerich T, Montfort JM. Bacteriocinogenic activity of lactobacilli from fermented sausages. Journal of Applied Bacteriology. 1993; 75: 142-148.

[56] Aymerich T, Martín B, Garriga M, Hugas M. Microbial quality and direct PCR identification of lactic acid bacteria and nonpathogenic staphylococci from artisanal low-acid sausages, Applied and Environmental. Microbiology. 2003; 69: 4583-4594.

[57] Vuyst LD, Falony G, Leroy F. Probiotics in fermented sausages. Meat science. 2008; 80: 75-78.

[58] Arihara K. Strategies for designing novel functional meat products. Meat Science. 2006; 74: 219-229.

[59] Stojanova M, Najdenovska O, Pejkovski Z, Trajcev M. The Influence of Some Starter Cultures on the Instrumental Values for Color of the Industrial Produced Macedonian Traditional Sausage. IOSR Journal of Engineering (IOSRJEN). 2017; 7: 44-49. 
World Journal of Biology Pharmacy and Health Sciences, 2021, 07(03), 046-056

[60] Stojanova M, Najdenovska 0, Pejkovski Z. The influence of two starter cultures on some quality properties of Macedonian traditional sausage. Journal of Agricultural, Food and Environmental Sciences. 2019; 73(3): 38-45.

[61] Hughes M, Garriga M, Aymerich T. Functionality of enterococci in meat products. International Journal of Food Microbiology. 2003; 88: 223-233. 